\title{
Agronomic Performance of Millet Plants Grown in Soil Fertilized With Organic Wastes
}

\author{
Wilker A. Morais ${ }^{1}$, Frederico A. L. Soares ${ }^{1}$, Fernando N. Cunha ${ }^{1}$, Marconi B. Teixeira ${ }^{1}$, Cicero T. S. Costa ${ }^{1}$, \\ Fernando R. Cabral Filho ${ }^{1}$, Gustavo da S. Vieira ${ }^{1}$, Vinícius de O. Marques ${ }^{1}$, Giovani S. Moraes ${ }^{1}$, \\ Daniely K. M. Alves ${ }^{1}$, Leandro S. Pereira ${ }^{1}$, Igor O. F. Silva ${ }^{1} \&$ Alef S. da S. Costa ${ }^{1}$ \\ ${ }^{1}$ Center of Agricultural Sciences, Instituto Federal Goiano-IF Goiano, Campus Rio Verde, Goiás, Brazil \\ Correspondence: Fernando N. Cunha, Center of Agricultural Sciences, Instituto Federal Goiano-Campus Rio \\ Verde, Goiás, Brazil. Tel: 55-64-3620-5600. E-mail: fernandonobrecunha@hotmail.com
}

Received: March 17, 2019

doi:10.5539/jas.v11n11p137
Accepted: May 21, $2019 \quad$ Online Published: July 31, 2019

URL: https://doi.org/10.5539/jas.v11n11p137

\begin{abstract}
Information on the potential of organic matter for soil fertility is important to an efficiently replenishment of nutrients. In this context, the objective of this work was to evaluate the agronomic performance of millet plants grown in soil fertilized with different rates of organic wastes, through biometric variables. A randomized block experimental design with a $4 \times 2$ factorial arrangement was used with four replications, consisting of 32 experimental units. The treatments consisted of four organic matter sources (swine manure, sewage sludge, bovine manure, and poultry litter), and two organic matter rates $\left(10\right.$ and $\left.20 \mathrm{dm}^{3}\right) ; 50 \mathrm{dm}^{3}$ pots filled with an agricultural soil that is predominant in the region were used. The pots were filled with $80 \%$ of soil and $20 \%$ of organic matter $\left(10 \mathrm{dm}^{3}\right)$; and with $60 \%$ of soil and $40 \%$ of organic matter $\left(20 \mathrm{dm}^{3}\right)$. Plant height $(\mathrm{PH})$, leaf area (LA), stem diameter (SD), and number of expanded leaves (NL) were evaluated at 20, 40, 60, and 80 days after sowing (DAS); panicle length (PNL), and panicle diameter (PD) were measured at 80 DAS. All biometric variables evaluated indicated that the better organic matter rate for soil fertilization for millet crops is $10 \mathrm{dm}^{3}$. In general, the highest panicle lengths and diameters were found in plants grown in soil with bovine manure.
\end{abstract}

Keywords: Pennisetum glaucum, bovine manure, poultry litter

\section{Introduction}

Unplanned population growth is the main cause of damage to physical, biotic, and socioeconomic environments (Sanchez, 2008). In this context, one of the difficulties for a sustainable development is the inadequate waste disposal. Organic wastes can contaminate soil, water resources, vegetation, animals, and humans, and result in economic losses (Sisinno et al., 2003). Information on the potential of organic matter for soil fertility is important to an efficiently replenishment of nutrients that are necessary for plant growth, and soil physical improvement (Lopes, 2007).

Organic fertilization and soil recovery can balance the soil physical, chemical, and biological conditions (Ferreira et al., 2010), and reduce the use of chemical fertilizers in agricultural areas. The use of chemical fertilizers to increase soil nutrients, and poor soil managements can cause problems related to soil degradation, such as decrease in organic matter, salinization, soil depletion, and soil erosion (Silva et al., 2007). Thus, soils with plenty of organic matter can be cultivated with diverse crops, such as millet, a crop that has been increasingly used in agricultural areas. The use of poultry litter and swine manure as a source of nitrogen in major grain crops well documented in the literature; due to the high nitrogen content in these organic matter and the high demand of $\mathrm{N}$ by grasses, these plants presents, in most cases, positive responses to the organic matter application (Musa et al., 2012; Lyimo et al., 2012; Pinto et al., 2014; Basso et al., 2017). In addition it should also be considered, there need strategies to reduce the volume of waste, maximize their fertilization potential and reduce the environmental pollution (Silva et al., 2016).

Millet (Pennisetum glaucum L.) is a widely used annual grass in India and some African countries. The millet planted area has been increasingly grown in Brazil, especially in the Cerrado biome, which has low-fertility soils and long annual dry seasons. This crop is used to produce green biomass for forage, dry biomass for soil cover in no-tillage system, and grain production for animal feed, and seeds (Fontaneli et al., 2012). Compared to other traditional crops such as soybeans and corn, millet (Panicum miliaceum L.) is a lesser-known culture and studies 
regarding this crop are still uncommon (Basso et al., 2017).

In this context, the objective of this work was to evaluate the agronomic performance of millet plants grown in a Latosol fertilized with different sources and rates of organic wastes, through biometric variables.

\section{Materials and Methods}

The experiment was conducted in a greenhouse at the Federal Institute of Goiás, Rio Verde county, southwest of the Goiás state, Brazil $\left(17^{\circ} 47^{\prime} 53^{\prime \prime} \mathrm{N}, 51^{\circ} 55^{\prime} 53^{\prime \prime} \mathrm{S}\right.$, and altitude of $\left.743 \mathrm{~m}\right)$. The soil was characterized as Dystroferric Red Latosol (Oxisol) (Embrapa, 2013). According to Köppen and Geiger (1928), the climate of the region is classified as Aw (tropical), with rains from October to May and dry period from June to September. The mean annual temperature varies from 20 to $35^{\circ} \mathrm{C}$ and the rainfalls oscillate between 1,500 and 1,800 mm per year.

A randomized block experimental design with a $4 \times 2$ factorial arrangement was used with four replications, consisting of 32 experimental units. The treatments consisted of four organic matter sources (swine manure, sewage sludge, bovine manure, and poultry litter), and two organic matter rates $\left(10\right.$ and $\left.20 \mathrm{dm}^{3}\right) ; 50 \mathrm{dm}^{3}$ pots filled with an agricultural soil that is predominant in the region were used. The pots were filled with $80 \%$ of soil and $20 \%$ of organic matter $\left(10 \mathrm{dm}^{3}\right)$; and with $60 \%$ of soil and $40 \%$ of organic matter $\left(20 \mathrm{dm}^{3}\right)$. The soil chemical analysis after the treatments is shown in Table 1. The soil analysis was performed according to Silva et al. (2009).

Table 1. Analysis of macronutrients and micronutrients of soil treated with organic wastes and used for the planting of millet

\begin{tabular}{|c|c|c|c|c|c|c|c|c|}
\hline \multirow{2}{*}{ Treatments } & \multicolumn{7}{|c|}{ Macronutrients $^{1}$} & \multirow{2}{*}{$\mathrm{pH}$} \\
\hline & $\mathrm{Ca}$ & $\mathrm{Mg}$ & $\mathrm{Al}$ & $\mathrm{K}$ & $\mathrm{K}$ & $\mathrm{S}$ & $\mathrm{P}$ & \\
\hline & \multicolumn{4}{|c|}{ - } & \multicolumn{3}{|c|}{ 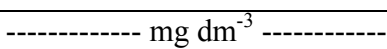 } & \\
\hline SM $20 \%$ & 4.44 & 1.14 & 0.00 & 0.32 & 126.0 & 114.9 & 33.40 & 6.2 \\
\hline SM $40 \%$ & 4.43 & 1.15 & 0.01 & 0.34 & 133.0 & 116.8 & 23.35 & 5.5 \\
\hline SS $20 \%$ & 3.20 & 0.94 & 0.05 & 0.32 & 126.0 & 101.2 & 21.85 & 4.9 \\
\hline SS $40 \%$ & 3.28 & 0.83 & 0.10 & 0.30 & 119.0 & 161.3 & 20.79 & 4.7 \\
\hline BM $20 \%$ & 2.33 & 1.18 & 0.00 & 0.91 & 356.0 & 12.5 & 28.39 & 7.1 \\
\hline BM $40 \%$ & 3.76 & 2.35 & 0.00 & 1.67 & 652.0 & 20.1 & 87.70 & 7.3 \\
\hline PL 20\% & 1.92 & 2.06 & 0.00 & 0.00 & 1.3 & 72.1 & 154.49 & 8.1 \\
\hline PL $40 \%$ & 1.44 & 3.06 & 0.00 & 0.01 & 2.4 & 181.1 & 263.09 & 8.3 \\
\hline \multirow{2}{*}{ Treatments } & \multicolumn{6}{|c|}{ Micronutrients } & \multirow{2}{*}{$\mathrm{OM}$} & \multirow{2}{*}{ CEC } \\
\hline & $\mathrm{Na}$ & $\mathrm{Fe}$ & $\mathrm{Mn}$ & $\mathrm{Cu}$ & $\mathrm{Zn}$ & B & & \\
\hline & \multicolumn{6}{|c|}{ 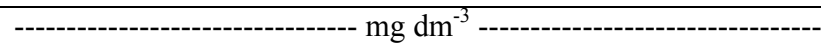 } & $\mathrm{g} \mathrm{dm}^{-3}$ & $\mathrm{cmol}_{\mathrm{c}} \mathrm{dm}^{-3}$ \\
\hline SM $20 \%$ & 19.00 & 13.85 & 53.74 & 5.59 & 19.54 & 0.16 & 35.7 & 7.69 \\
\hline SM $40 \%$ & 18.00 & 12.07 & 54.41 & 2.20 & 10.33 & 0.28 & 39.6 & 8.32 \\
\hline SS $20 \%$ & 37.00 & 69.91 & 96.20 & 5.09 & 18.16 & 0.29 & 34.1 & 8.04 \\
\hline SS $40 \%$ & 45.00 & 90.36 & 118.05 & 3.26 & 21.01 & 0.23 & 39.0 & 8.10 \\
\hline BM $20 \%$ & 33.00 & 12.39 & 47.70 & 3.04 & 5.75 & 0.18 & 30.3 & 5.59 \\
\hline $\mathrm{BM} 40 \%$ & 55.00 & 15.05 & 110.07 & 3.09 & 11.27 & 0.31 & 49.8 & 9.01 \\
\hline PL 20\% & 360.00 & 12.10 & 111.89 & 8.17 & 10.78 & 1.94 & 31.0 & 6.25 \\
\hline PL $40 \%$ & 240.00 & 8.66 & 127.61 & 5.60 & 14.40 & 2.49 & 51.3 & 6.21 \\
\hline
\end{tabular}

Note. ${ }^{1}$ Macronutrients and Micronutrients. Treatments: swine manure (SM); sewage sludge (SS); bovine manure (BM); poultry litter (PL); organic matter (OM); cation exchange capacity (CEC); $20 \%$ of organic matter $\left(10 \mathrm{dm}^{3}\right)$ and $40 \%$ of organic matter $\left(20 \mathrm{dm}^{3}\right)$.

Seeds of millet (EMBRAPA BRS 1501) were sowed in April 2016 using ten seeds per pot. Thinning was performed at 15 days after sowing (DAS), leaving the three better developed plants to measure biometric variables.

Plant height (PH), leaf area (LA), stem diameter (SD), and number of expanded leaves (NL) were evaluated at 20, 40, 60, and 80 DAS; panicle length (PNL), and panicle diameter (PD) were measured at 80 DAS.

PH was measured from the ground to the base of the millet panicle. The leaf length (LL) and width (LW)-measured in the central wider regions of the fourth leaf from the base of the plant-were measured to 
determine the LA, using the equation $L A=L L \times L W \times 0.75$ (Sangoi et al., 2011). These measurements were performed using a metric ruler. SD was measured near the ground, using a digital caliper with precision of 0.01 $\mathrm{mm}$, and PNL was measured using a metric ruler. Panicle diameter was measured in the central part of each panicle, using a digital caliper with precision of $0.01 \mathrm{~mm}$.

The data of each variable were subjected to analysis of variance using the SISVAR program (Ferreira, 2011). Significant variables by the $\mathrm{F}$ test were submitted to the Tukey's means test at $5 \%$ probability for the sources and rates of organic matter.

\section{Results and Discussion}

The millet vegetative and reproductive growth was evaluated through their biometric variables, stem diameter $(\mathrm{SD})$, plant height $(\mathrm{PH})$, number of leaves $(\mathrm{NL})$, and leaf area (LA) are important variables to compare fertilization treatments.

The interaction between organic matters sources (OMS) and organic matter rates (OMR) was significant for SD at 20,40,60, and 80 DAS (Table 2). OMS had significant isolated effect only at 80 DAS, whereas OMR had significant effect at all evaluation times.

Table 2. ANAVA to evaluate the significance of the sources of variation of stem diameter (SD), plant height (PH), number of leaves and leaf area (LA) in millet

\begin{tabular}{|c|c|c|c|c|c|}
\hline \multirow{2}{*}{ SV } & \multirow{2}{*}{$\mathrm{DF}$} & \multicolumn{4}{|c|}{ Stem diameter } \\
\hline & & $20 \mathrm{DAS}$ & 40 DAS & 60 DAS & 80 DAS \\
\hline & & Mean square & & & \\
\hline OMS & 3 & $27.95^{* *}$ & $12.58^{* *}$ & $8.56^{*}$ & $4.41^{\mathrm{ns}}$ \\
\hline OMR & 1 & $10.79^{* *}$ & $15.47^{* *}$ & $15.88^{*}$ & $18.09^{*}$ \\
\hline $\mathrm{OMS} \times \mathrm{OMR}$ & 3 & $6.25^{* *}$ & $13.50^{* *}$ & $26.52^{* *}$ & $55.51^{* *}$ \\
\hline Block & 3 & $0.27^{\mathrm{ns}}$ & $2.29^{\mathrm{ns}}$ & $1.52^{\mathrm{ns}}$ & $6.14^{\mathrm{ns}}$ \\
\hline Residual & 21 & 0.34 & 0.79 & 2.12 & 3.43 \\
\hline $\mathrm{CV}(\%)$ & & 5.11 & 6.58 & 9.96 & 11.54 \\
\hline \multirow{2}{*}{ SV } & \multirow{2}{*}{ DF } & \multicolumn{4}{|c|}{ Plant height } \\
\hline & & $20 \mathrm{DAS}$ & $40 \mathrm{DAS}$ & 60 DAS & $80 \mathrm{DAS}$ \\
\hline OMS & 3 & $0.04^{* *}$ & $0.02^{* *}$ & $0.55^{* *}$ & $0.42^{* *}$ \\
\hline OMR & 1 & $0.00001^{\mathrm{ns}}$ & $0.00003^{\mathrm{ns}}$ & $0.15^{* *}$ & $0.28^{* *}$ \\
\hline $\mathrm{OMS} \times \mathrm{OMR}$ & 3 & $0.02^{* *}$ & $0.0009^{\mathrm{ns}}$ & $0.28^{* *}$ & $0.69^{* *}$ \\
\hline Block & 3 & $0.0009^{\mathrm{ns}}$ & $0.005^{\mathrm{ns}}$ & $0.01^{\mathrm{ns}}$ & $0.06^{\mathrm{ns}}$ \\
\hline Residual & 21 & 0.0005 & 0.002 & 0.01 & 0.02 \\
\hline $\mathrm{CV}(\%)$ & & 8.78 & 9.04 & 10.67 & 9.78 \\
\hline \multirow{2}{*}{ SV } & \multirow{2}{*}{ DF } & \multicolumn{4}{|c|}{ Number leaves } \\
\hline & & $20 \mathrm{DAS}$ & 40 DAS & 60 DAS & 80 DAS \\
\hline OMS & 3 & $0.11^{\mathrm{ns}}$ & $0.71^{\mathrm{ns}}$ & $1.03^{*}$ & $1.03^{\mathrm{ns}}$ \\
\hline OMR & 1 & $1.53^{\mathrm{ns}}$ & $0.50^{\mathrm{ns}}$ & $1.53^{*}$ & $0.78^{\mathrm{ns}}$ \\
\hline $\mathrm{OMS} \times \mathrm{OMR}$ & 3 & $1.53^{*}$ & $1.75^{* *}$ & $2.36^{* *}$ & $0.53^{\mathrm{ns}}$ \\
\hline Block & 3 & $0.11^{\mathrm{ns}}$ & $0.71^{\mathrm{ns}}$ & $0.53^{\mathrm{ns}}$ & $0.86^{\mathrm{ns}}$ \\
\hline Residual & 21 & 0.47 & 0.33 & 0.25 & 0.41 \\
\hline $\mathrm{CV}(\%)$ & & 11.63 & 8.40 & 6.42 & 8.12 \\
\hline \multirow{2}{*}{ SV } & \multirow{2}{*}{ DF } & \multicolumn{4}{|c|}{ Leaf area } \\
\hline & & 20 DAS & $40 \mathrm{DAS}$ & $60 \mathrm{DAS}$ & 80 DAS \\
\hline OMS & 3 & $724.59^{* *}$ & $4119.62^{*}$ & $2748.30^{*}$ & $28325.37^{* *}$ \\
\hline OMR & 1 & $719.34^{*}$ & $10.25^{\mathrm{ns}}$ & $5383.59^{*}$ & $2771.40^{\mathrm{ns}}$ \\
\hline $\mathrm{OMS} \times \mathrm{OMR}$ & 3 & $359.62^{\mathrm{ns}}$ & $412.37^{\mathrm{ns}}$ & $116.04^{\mathrm{ns}}$ & $2753.41^{\mathrm{ns}}$ \\
\hline Block & 3 & $88.50^{\mathrm{ns}}$ & $637.24^{\mathrm{ns}}$ & $137.41^{\mathrm{ns}}$ & $1343.01^{\mathrm{ns}}$ \\
\hline Residual & 21 & 128.57 & 903.62 & 777.94 & 1034.75 \\
\hline $\mathrm{CV}(\%)$ & & 14.48 & 18.12 & 11.12 & 8.52 \\
\hline
\end{tabular}

Note. ${ }^{1}$ Source of variation (SV); degree of freedom (DF); organic matter source (OMS); organic matter rate (OMR); coefficient of variation (CV); days after sowing (DAS); ${ }^{*}$ significant at $5 \%$ by the $\mathrm{F}$ test; ${ }^{* *}$ significant at $1 \%$ by the $\mathrm{F}$ test and ${ }^{\mathrm{ns}}$ not significant at $5 \%$ by the $\mathrm{F}$ test. 
Galbiatti et al. (2011) also reported growth response of pearl millet to biofertilizer application compared to other fertilizers.

The interaction between OMS and OMR was significant for PH at 20,60, and 80 DAS (Table 2). OMS had an isolated effect at all evaluation times, and OMR had an isolated effect at 60 and 80 DAS.

The interaction between OMS and OMR was significant for NL at 20,40, and 60 DAS. OMS and OMR had isolated effects only at 60 DAS.

Vital et al. (2015) verified that the different sources of organic fertilization significantly influenced some phytometric variables, an increase in productivity of dry and fresh plant material with the application of organic compost and manure.

The interaction between OMS and OMR was not significant for LA at any evaluation time, which presented significant differences at 20,40,60, and 80 DAS due to the OMS, and at 20 and 60 DAS due to the OMR.

SD is important for plant support; the larger the plant diameter, the greater the plant's resistance to lodging (Taiz \& Zeiger, 2013). The highest SD with the OMR of $10 \mathrm{dm}^{3}$ during the vegetative and reproductive stages, were found in millet plants in soil with bovine manure $(12.70$ to $20.39 \mathrm{~mm})$. Plants in soil with the OMR of $20 \mathrm{dm}^{3}$ had the highest SD with swine manure $(12.80$ to $18.20 \mathrm{~mm})$. Plants in soil with the OMR of $10 \mathrm{dm}^{3}$ had, in general, the highest SD values; this was probably due to the phytotoxicity caused by excess nutrients applied through the organic matter.

Guimarães Júnior et al. (2009) evaluate agronomic characteristics of three millet genotypes (CMS-1, BRS-1501, and BN-2) using soil fertilization with $350 \mathrm{~kg} \mathrm{ha}^{-1}$ of NPK (8-28-16) and topdressing with $100 \mathrm{~kg} \mathrm{ha}^{-1}$ of urea, according to soil analysis and the crop requirements (winter millet) and found SD of $13.17 \mathrm{~mm}$ (37 DAS), 13.93 $\mathrm{mm}$ (52 DAS), $12.80 \mathrm{~mm}$ (67 DAS), and $13.56 \mathrm{~mm}$ (82 DAS). These results are similar to those found in the present work for millet plants in soil with poultry litter (PL), and sewage sludge (SS) (Table 3). Plants in soil with SM, and BM presented higher SD when using SM at OMR of $20 \mathrm{dm}^{3}(18.20 \mathrm{~mm})$, or BM at OMR of 10 $\mathrm{dm}^{3}(20.39 \mathrm{~mm})$.

Table 3. Effect of organic matter sources (OMS) and organic matter rates (OMR) on stem diameter (SD) of millet pants at different days after sowing (DAS)

\begin{tabular}{|c|c|c|c|c|}
\hline \multirow{3}{*}{$\operatorname{OMR}\left(\mathrm{dm}^{3}\right)$} & \multicolumn{4}{|c|}{ OMS } \\
\hline & \multicolumn{4}{|c|}{ Stem diameter $(\mathrm{mm})$} \\
\hline & $\mathrm{PL}$ & SM & $\mathrm{BM}$ & $\mathrm{SS}$ \\
\hline \multicolumn{5}{|l|}{$20 D A S$} \\
\hline 10 & $10.58 \mathrm{aB}$ & $12.47 \mathrm{aA}$ & $12.70 \mathrm{aA}$ & $12.73 \mathrm{aA}$ \\
\hline 20 & $6.94 \mathrm{bC}$ & $12.80 \mathrm{aA}$ & $11.51 \mathrm{bB}$ & $12.57 \mathrm{aAB}$ \\
\hline \multicolumn{5}{|l|}{$40 D A S$} \\
\hline 10 & $12.85 \mathrm{aBC}$ & $12.65 \mathrm{bC}$ & $16.91 \mathrm{aA}$ & $14.54 \mathrm{aB}$ \\
\hline 20 & $10.83 \mathrm{bC}$ & $14.79 \mathrm{aA}$ & $12.82 \mathrm{bB}$ & $12.94 \mathrm{bB}$ \\
\hline \multicolumn{5}{|l|}{$60 D A S$} \\
\hline 10 & $14.76 \mathrm{aB}$ & $13.22 \mathrm{bB}$ & $17.97 \mathrm{aA}$ & $15.32 \mathrm{aAB}$ \\
\hline 20 & $11.65 \mathrm{bB}$ & $16.91 \mathrm{aA}$ & $13.27 \mathrm{bB}$ & $13.81 \mathrm{aB}$ \\
\hline \multicolumn{5}{|l|}{$80 D A S$} \\
\hline 10 & $17.68 \mathrm{aAB}$ & $13.50 \mathrm{bC}$ & $20.39 \mathrm{aA}$ & $15.65 \mathrm{aBC}$ \\
\hline 20 & $12.79 \mathrm{bC}$ & $18.20 \mathrm{aA}$ & $13.65 \mathrm{bBC}$ & $16.57 \mathrm{aAB}$ \\
\hline
\end{tabular}

Note. ${ }^{1}$ Means followed by the same lowercase letter in the columns and uppercase letter in the rows do not differ by the Tukey's test at $5 \%$ probability. Organic matter source (OMS); organic matter rate (OMR); poultry litter (PL); swine manure (SM); bovine manure (BM); sewage sludge (SS).

Plants grown in soil with SS had higher PH $(0.66 \mathrm{~m})$ than those in soil with SM $(0.57 \mathrm{~m})$ or BM $(0.57 \mathrm{~m})$ at 40 DAS (Table 4). 
Table 4. Plant height (PH) of millet plants at 40 days after sowing (DAS) as a function of different organic matter sources (OMS)

\begin{tabular}{ll}
\hline OMS & Plant height $(\mathrm{m})$ \\
\hline PL & $0.61 \mathrm{ab}$ \\
SM & $0.57 \mathrm{~b}$ \\
BM & $0.57 \mathrm{~b}$ \\
SS & $0.66 \mathrm{a}$ \\
\hline
\end{tabular}

Note. ${ }^{1}$ Means followed by the same letter in the treatments do not differ by the Tukey's test at $5 \%$ probability. Organic matter source (OMS); poultry litter (PL); swine manure (SM); bovine manure (BM); sewage sludge (SS).

Plants in soil with SM at OMR of $10 \mathrm{dm}^{3}$ had the highest PH (2.11 m) (Table 5). Plants in soil with the OMR of $10 \mathrm{dm}^{3}$ had the lowest PH when using poultry litter $(0.80 \mathrm{~m})$. Plants in soil with the OMR of $20 \mathrm{dm}^{3}$ had the highest PH in soil with BM (1.92 m), and the lowest in soil with PL $(0.68 \mathrm{~m})$. Plants in soil with BM had the highest PH when using OMR of $20 \mathrm{dm}^{3}$; the other OMS presented higher PH when using OMR of $10 \mathrm{dm}^{3}$. Guimarães Júnior et al. (2009) found PH of $0.78 \mathrm{~m}$ (37 DAS), $2.03 \mathrm{~m}$ (52 DAS), $2.13 \mathrm{~m}$ (67 DAS) and $2.40 \mathrm{~m}$ (82 DAS) for millet genotypes (CMS-1, BRS-1501, and BN-2) grown in winter. These are similar values to those found in the present work for all OMS and OMR. Pinho et al. (2013) evaluated millet genotypes for silage in a semiarid region and found maximum PH of $0.60 \mathrm{~m}$ (Sauna B genotype), $0.67 \mathrm{~m}$ (CMS 01 genotype), $0.90 \mathrm{~m}$ (ADR 500 genotype), $0.79 \mathrm{~m}$ (BRS 1501 genotype) and $1.02 \mathrm{~m}$ (CMS 03 genotype).

Table 5. Effect of organic matter sources (OMS) and organic matter rates (OMR) on plant height of millet pants at different days after sowing (DAS)

\begin{tabular}{|c|c|c|c|c|}
\hline \multirow{3}{*}{$\operatorname{OMR}\left(\mathrm{dm}^{3}\right)$} & \multicolumn{4}{|c|}{ OMS } \\
\hline & \multicolumn{4}{|c|}{ Plant height $(\mathrm{m})$} \\
\hline & PL & SM & $\mathrm{BM}$ & $\mathrm{SS}$ \\
\hline \multicolumn{5}{|l|}{$20 D A S$} \\
\hline 10 & $0.17 \mathrm{aB}$ & $0.27 \mathrm{aA}$ & $0.26 \mathrm{bA}$ & $0.29 \mathrm{aA}$ \\
\hline 20 & $0.14 b C$ & $0.23 \mathrm{bB}$ & $0.40 \mathrm{aA}$ & $0.23 \mathrm{bB}$ \\
\hline \multicolumn{5}{|l|}{$60 D A S$} \\
\hline 10 & $0.80 \mathrm{aC}$ & $1.43 \mathrm{aA}$ & $1.17 \mathrm{bB}$ & $1.26 \mathrm{aAB}$ \\
\hline 20 & $0.68 \mathrm{bC}$ & $0.94 \mathrm{bB}$ & $1.55 \mathrm{aA}$ & $0.96 \mathrm{bB}$ \\
\hline \multicolumn{5}{|l|}{$80 D A S$} \\
\hline 10 & $1.15 \mathrm{aC}$ & $2.11 \mathrm{aA}$ & $1.44 \mathrm{bBC}$ & $1.69 \mathrm{aB}$ \\
\hline 20 & $1.22 \mathrm{aB}$ & $1.24 \mathrm{bB}$ & $1.92 \mathrm{aA}$ & $1.26 \mathrm{bB}$ \\
\hline
\end{tabular}

Note. ${ }^{1}$ Means followed by the same lowercase letter in the columns and uppercase letter in the rows do not differ by the Tukey's test at 5\% probability. Organic matter source (OMS); organic matter rate (OMR); poultry litter (PL); swine manure (SM); bovine manure (BM); sewage sludge (SS).

The OMR affected the NL of plants in soil with BM, and SS at 20 DAS. Plants in soil with BM had the highest NL (8.5) when using OMR of $10 \mathrm{dm}^{3}$. No differences in NL were found between OMS with the same OMR (Table 6). 
Table 6. Effect of organic matter sources (OMS) and organic matter rates (OMR) on number leaves of millet pants at different days after sowing (DAS)

\begin{tabular}{|c|c|c|c|c|}
\hline \multirow{3}{*}{$\mathrm{OMR}\left(\mathrm{dm}^{3}\right)$} & \multicolumn{4}{|c|}{ OMS } \\
\hline & \multicolumn{4}{|c|}{ Number leaves } \\
\hline & PL & SM & $\mathrm{BM}$ & SS \\
\hline \multicolumn{5}{|l|}{$20 D A S$} \\
\hline 10 & $5.50 \mathrm{aA}$ & $6.00 \mathrm{aA}$ & $6.75 \mathrm{aA}$ & $6.25 \mathrm{aA}$ \\
\hline 20 & $6.00 \mathrm{aA}$ & $6.00 \mathrm{aA}$ & $5.25 \mathrm{bA}$ & $5.50 \mathrm{bA}$ \\
\hline \multicolumn{5}{|l|}{$40 D A S$} \\
\hline 10 & $6.75 \mathrm{aAB}$ & $7.25 \mathrm{aAB}$ & $7.50 \mathrm{aA}$ & $6.25 \mathrm{aB}$ \\
\hline 20 & $6.50 \mathrm{aAB}$ & $7.25 \mathrm{aA}$ & $6.00 \mathrm{bB}$ & $7.00 \mathrm{aAB}$ \\
\hline \multicolumn{5}{|l|}{$60 D A S$} \\
\hline 10 & $7.75 \mathrm{aAB}$ & $8.25 \mathrm{aA}$ & $8.50 \mathrm{aA}$ & $7.25 \mathrm{aB}$ \\
\hline 20 & $7.50 \mathrm{aA}$ & $8.25 \mathrm{aA}$ & $6.50 \mathrm{bB}$ & $7.75 \mathrm{aA}$ \\
\hline
\end{tabular}

Note. ${ }^{1}$ Means followed by the same lowercase letter in the columns and uppercase letter in the rows do not differ by the Tukey's test at 5\% probability. Organic matter source (OMS); organic matter rate (OMR); poultry litter $(\mathrm{PL})$; swine manure (SM); bovine manure (BM); sewage sludge (SS).

The OMR affected the NL of plants in soil with BM at 40 DAS. Plants in soil with the OMR of $10 \mathrm{dm}^{3}$ had the highest NL.

Plants in soil with BM had higher NL than those in soil with SS, when using the OMF of $10 \mathrm{dm}^{3}$; plants grown in soil with SM had higher NL (8.25) than those in soil with BM when using the OMR of $20 \mathrm{dm}^{3}$ (Table 6).

According Ibrahim et al. (2015) the highest values of plant height $(125.61 \mathrm{~cm})$, number of tillers $/ \mathrm{m}(95.56)$, stem diameter $(1.82 \mathrm{~cm})$ and leaf $/$ stem ratio $(0.52)$ were recorded in treatment with $75 \% \mathrm{~N}+$ Microbin +3 ton fed compost.

The effect of OMR on NL of plants evaluated at 60 DAS was similar to that of plants evaluated at 40 DAS. Plants in soil with SM, and BM at OMR of $10 \mathrm{dm}^{3}$ had higher NL than those in soil with LE. Plants in soil with PL, SM, and LE had the higher NL, when using the OMR of $20 \mathrm{dm}^{3}$.

Streck et al. (2009) found similar NL at 60 DAS and 80 DAS in millet plants (8.4 leaves per plant) when estimating the base temperature for leaf emergence and the phyllochron of maize using different sowing dates in two years.

Plants in soil with SM $\left(88.65 \mathrm{~cm}^{2}\right)$, and BM $\left(83.58 \mathrm{~cm}^{2}\right)$ had greater leaf areas at 20 DAS than those in soil with PL (67.72). Plants in soil with the OMR of $10 \mathrm{dm}^{3}$ had the highest LA $\left(83.06 \mathrm{~cm}^{2}\right)$ at 20 DAS (Table 7). Plants in soil with SS had similar LA to those of plants in the other treatments.

Table 7. Leaf area of millet plants at 20,40,60, and 80 days after sowing (DAS) as a function of organic matter sources (OMS) and organic matter rates (OMR)

\begin{tabular}{lllll}
\hline \multirow{2}{*}{ OMS } & \multicolumn{4}{c}{ Leaf area $\left(\mathrm{cm}^{2}\right)$} \\
\cline { 2 - 5 } & 20 DAS & 40 DAS & 60 DAS & 80 DAS \\
\hline PL & $67.72 \mathrm{~b}$ & $132.10 \mathrm{~b}$ & $224.05 \mathrm{~b}$ & $291.89 \mathrm{~b}$ \\
$\mathrm{SM}$ & $88.65 \mathrm{a}$ & $175.23 \mathrm{a}$ & $254.99 \mathrm{ab}$ & $388.69 \mathrm{a}$ \\
$\mathrm{BM}$ & $83.58 \mathrm{a}$ & $180.83 \mathrm{a}$ & $266.94 \mathrm{a}$ & $428.71 \mathrm{a}$ \\
$\mathrm{SS}$ & $73.31 \mathrm{ab}$ & $175.52 \mathrm{a}$ & $256.88 \mathrm{ab}$ & $400.84 \mathrm{a}$ \\
\hline \multirow{2}{*}{ OMR $\left(\mathrm{dm}^{3}\right)$} & & Leaf area $\left(\mathrm{cm}^{2}\right)$ & \\
\cline { 2 - 5 } 10 & $20 \mathrm{DAS}$ & $60 \mathrm{DAS}$ & \\
20 & $83.06 \mathrm{a}$ & $237.75 \mathrm{~b}$ & \\
\hline
\end{tabular}

Note. ${ }^{1}$ Means followed by the same lowercase letter in the columns and uppercase letter in the rows do not differ by the Tukey's test at $5 \%$ probability. Organic matter source (OMS); organic matter rate (OMR); poultry litter (PL); swine manure (SM); bovine manure (BM); sewage sludge (SS). 
Plants in soil with SM (175.23 and $\left.388.69 \mathrm{~cm}^{2}\right)$, BM $\left(180.83\right.$ and $\left.428.71 \mathrm{~cm}^{2}\right)$, and SS $\left(175.52\right.$ and $\left.400.84 \mathrm{~cm}^{2}\right)$ had the highest LA at 40, and 80 DAS. Plants in soil with BM $\left(266.94 \mathrm{~cm}^{2}\right)$ had higher LA than those in soil with PL $\left(224.05 \mathrm{~cm}^{2}\right)$ at 60 DAS. Plants in soil with the OMR of $20 \mathrm{dm}^{3}$ had higher LA $\left(263.69 \mathrm{~cm}^{2}\right)$ than those in soil with the OMR of $10 \mathrm{dm}^{3}$ at 60 DAS.

Brito et al. (2011) evaluated the effect of LA on agronomic characters of maize plants and found similar maximum LA to that obtained in the present work, when the leaves were evaluated individually.

The OMS, OMR, and the interaction between OMS and OMR were significant for panicle length and panicle diameter (Table 8).

Table 8. ANAVA to evaluate the significance of the sources of variation of panicle length (PNL) and panicle diameter $(\mathrm{PD})$ in millet

\begin{tabular}{llll}
\hline \multirow{2}{*}{ SV } & DF & \multicolumn{2}{c}{ Mean square } \\
\cline { 3 - 4 } & & PNL & PD \\
\hline OMS & 3 & $22.38^{* *}$ & $7.20^{* *}$ \\
OMR & 1 & $7.51^{*}$ & $30.17^{* *}$ \\
OMS $\times$ OMR & 3 & $13.22^{* *}$ & $18.97^{* *}$ \\
Block & 3 & $0.34^{\mathrm{ns}}$ & $0.003^{\mathrm{ns}}$ \\
Residual & 21 & 0.60 & 0.46 \\
CV $(\%)$ & & 2.90 & 3.01 \\
\hline
\end{tabular}

Note. ${ }^{1}$ Source of variation (SV); degree of freedom (DF); organic matter source (OMS); organic matter rate (OMR); coefficient of variation (CV); days after sowing (DAS); ${ }^{*}$ significant at $5 \%$ by the $\mathrm{F}$ test; ${ }^{* *}$ significant at $1 \%$ by the $\mathrm{F}$ test and ${ }^{\mathrm{ns}}$ not significant at $5 \%$ by the $\mathrm{F}$ test.

The OMR had no effect on panicle length of plants is soil with BM. Plants in soil with the OMR of $10 \mathrm{dm}^{3}$ had higher panicle length than those in soil with the OMR of $20 \mathrm{dm}^{3}$, when using PL $(26.38 \mathrm{~cm})$, and SS $(27.25 \mathrm{~cm})$ (Table 9). Plants in soil with BM had higher panicle $(29.25 \mathrm{~cm}$ ) length than those in soil with the other OMS when using the OMR of $10 \mathrm{dm}^{3}$. Plants in soil with SM, and BM had higher panicle length $(28.50 \mathrm{~cm})$ than those in soil with the other OMS when using the OMR of $20 \mathrm{dm}^{3}$. Crusciol et al. (2011) found sorghum panicle length of $20.2 \mathrm{~cm}$, which was below the lowest value found in the present work for plants in soil with SS $(23.75 \mathrm{~cm})$ at OMR of $20 \mathrm{dm}^{3}$.

Table 9. Effect of the interaction between organic matter sources (OMS) and organic matter rates (OMR) on panicle length (PNL), and panicle diameter (PD) of millet plants

\begin{tabular}{|c|c|c|c|c|}
\hline \multirow{2}{*}{$\operatorname{OMR}\left(\mathrm{dm}^{3}\right)$} & \multicolumn{4}{|c|}{ OMS } \\
\hline & PL & SM & $\mathrm{BM}$ & $\mathrm{SS}$ \\
\hline \multicolumn{5}{|l|}{$P N L(\mathrm{~cm})$} \\
\hline 10 & $26.38 \mathrm{aB}$ & $26.00 \mathrm{bB}$ & $29.25 \mathrm{aA}$ & $27.25 \mathrm{aB}$ \\
\hline 20 & $24.25 \mathrm{bB}$ & $28.50 \mathrm{aA}$ & $28.50 \mathrm{aA}$ & $23.75 \mathrm{bB}$ \\
\hline \multicolumn{5}{|l|}{$P D(\mathrm{~mm})$} \\
\hline 10 & $24.72 \mathrm{aA}$ & $21.64 \mathrm{aB}$ & $25.96 \mathrm{aA}$ & $22.19 \mathrm{bB}$ \\
\hline 20 & $20.09 \mathrm{bC}$ & $21.36 \mathrm{aBC}$ & $21.55 \mathrm{bB}$ & $23.74 \mathrm{aA}$ \\
\hline
\end{tabular}

Note. ${ }^{1}$ Means followed by the same lowercase letter in the columns and uppercase letter in the rows do not differ by the F-test at $5 \%$ probability. Organic matter source (OMS); organic matter rate (OMR); poultry litter (PL); swine manure (SM); bovine manure (BM); sewage sludge (SS).

The OMR were not significant for panicle diameter of plants in soil with SM. Plants in soil with PL, and BM had higher panicle diameter when using the OMR of $10 \mathrm{dm}^{3}$ (Table 9). Azraf-ul-Hag et al. (2007) reported that use of $50 \% \mathrm{NP}+50 \%$ poultry manure gave the highest crop yield. Plants in soil with PL $(24.72 \mathrm{~cm})$, and BM $(25.96 \mathrm{~cm})$ had higher panicle diameter than those in soil with the other OMS when using the OMR of $10 \mathrm{dm}^{3}$. Plants in soil with SS had the highest panicle diameter $(23.74 \mathrm{~cm})$, and those in soil with PL had the lowest panicle diameter $(20.09 \mathrm{~cm})$ when using the OMR of $20 \mathrm{dm}^{3}$. 


\section{Conclusion}

Plants grown in soil with bovine manure had best results for stem diameter, plant height, number of leaves, and leaf area.

All biometric variables evaluated indicated that the better organic matter rate for soil fertilization for millet crops is $10 \mathrm{dm}^{3}$.

\section{Acknowledgements}

The authors would like to thank the Ministry of Science, Technology, Innovation and Communications (MCTIC), the Foundation for Research Support of the State of Goiás (FAPEG), the Brazilian National Council for Scientific and Technological Development $(\mathrm{CNPq})$, and the Coordination for the Improvement of Higher Education Personnel (CAPES). Financier of Studies and Projects (FINEP) and Federal Institute of Education, Science and Technology Goiano (IFGoiano)-Campus Rio Verde, Goiás, supported the work.

\section{References}

Azraf-ul-Hag, A., Qadir, I., \& Mahmood, N. (2007). Effect of integrated use of organic and inorganic fertilizers on fodder yield of sorghum (Sorghum Bicolor L.). Pak. J. Agri. Sci., 44(3), 415-421.

Basso, C. J., Muraro, D. S., Girotto, E., Silva, D. R. O., \& Silva, A. N. (2017). Poultry litter and swine compost as nutrients sources in Millet. Biosci. J., 33(2), 288-296. https://doi.org/10.14393/BJ-v33n2-33059

Brito, C. H., Silveira, D. L., Brandão, A. M., Gomes, L. S., \& Lopes, M. T. G. (2011). Redução de área foliar em milho em região tropical no Brasil e os efeitos em caracteres agronômicos. Interciencia, 36(4), 291-295.

Embrapa (Empresa Brasileira de Pesquisa Agropecuária). (2013). Sistema brasileiro de classificação de solos. Centro Nacional de Pesquisa de Solos (3rd ed., pp. 1-353). Brasília: Embrapa.

Ferreira, A. O., Sá, J. C. M., Nascimento, C. G., Briedis, C., \& Ramos, F. S. (2010). Impacto de resíduos orgânicos de abatedouro de aves e suínos na produtividade do feijão na região dos campos gerais-PR-Brasil. Revista Verde, 5(4), 15-21. https://doi.org/10.18378/rvads.v5i4.340

Ferreira, D. F. (2011). Sisvar: A computer statistical analysis system. Ciência e Agrotecnologia, 35(6), 1039-1042. https://doi.org/10.1590/S1413-70542011000600001

Fontaneli, R. S., Fontaneli, R. S., \& Santos, H. P. (2012). Gramíneas forrageiras anuais de verão. In R. S. Fontaneli, H. P. Santos, \& R. S. Fontaneli (Eds.), Forrageiras para Integração Lavoura-Pecuária-Floresta na Região Sul-Brasileira (2nd ed., pp. 1-544). Brasília: Embrapa.

Galbiatti, J. A., Silva, F. G., Franco, C. F., \& Caramelo, A. D. (2011). Desenvolvimento do feijoeiro sob o uso de biofertilizante e a dubaçao mineral. Engenharia Agricola, 31, 167. https://doi.org/10.1590/S0100-69162 011000100017

Guimarães Júnior, R., Gonçalves, L. C., Rodrigues, J. A. S., Pires, D. A. A., Jayme, D. G., Rodriguez, N. M., \& Saliba, E. O. S. (2009). Avaliação agronômica de genótipos de milheto (P. glaucum) plantados em período de safrinha. Revista Archivos de Zootecnia, 58, 629-632.

Ibrahim, H. I. M., Hassanen, S. A. A., \& Hassan, E. A. (2015). Performance of Forage Millet in Response to Different Combinations of Organic-, Inorganic- and Bio-Fertilizers. World Journal of Agricultural Sciences, 11(6), 423-431.

Köppen, W., \& Geiger, R. (1928). Klimate der erde. Gotha: Verlag Justus Perthes, Wall-map.

Lopes, A. S., \& Guilherme, L. R. G. (2007). Fertilidade do solo e produtividade agrícola. In R. F. Novais, V. V. H. Alvarez, N. F. Barros, R. L. F. Fontes, R. B. Cantarutti, \& J. C. L. Neves (Eds.), Fertilidade do Solo (1st ed., pp. 1-64). Viçosa: SBCS.

Lyimo, H. J. F., Pratt, R. C., \& Mnyuku, R. S. O. W. (2012). Composted cattle and poultry manures provide excellent fertility and improved management of gray leaf spot in maize. Field Crops Research, 126, 97-103. https://doi.org/10.1016/j.fcr.2011.09.023

Musa, I. W., Sai'du, L., Kaltungo, Y. B., Abubakar, B. U., \& Wakawa, M. A. (2012). Poultry litter selection, management and utilization in Nigeria. Asian Journal of Poultry Science, 6(2), 44-55. https://doi.org/ 10.3923/ajpsaj.2012.44.55

Pinho, R. M. A., Santos, E. M., Rodrigues, J. A. S., Macedo, C. H. O., Campos, F. S., Ramos, J. P. F., ... Perazzo, A. F. (2013). Avaliação de genótipos de milheto para silagem no semiárido. Revista Brasileira de Saúde e Produção Animal, 14(3), 426-436. https://doi.org/10.1590/S1519-99402013000300003 
Pinto, M. A. B., Fabbris, C., Basso, C. J., Santi, A. L., \& Girotto, E. (2014). Aplicação de dejeto líquido de suínos e manejo do solo na sucessão aveia/milho. Pesquisa Agropecuária Tropical, 44(2), 205-212. https://doi.org/10.1590/S1983-40632014000200002

Sanchez, L. E. (2008). Avaliação de impacto ambiental: Conceitos e métodos (pp. 1-495). São Paulo: Of. de Text.

Sangoi, L., Schweitzer, C., Silva, P. R. F., Schmitt, A., Vargas, V. P., Casa, R. T., \& Souza, C. A. (2011). Perfilhamento, área foliar e produtividade do milho sob diferentes arranjos espaciais. Pesquisa agropecuária brasileira, 46(6), 609-616. https://doi.org/10.1590/S0100-204X2011000600006

Silva, A. N., Basso, C. J., Muraro, D. S., Ortigara, C., \& Pansera, E. (2016). Pig slurry composting as a nitrogen source in proso millet crop. Pesq. Agropec. Trop., 46(1), 80-88. https://doi.org/10.1590/1983-40632 016v4638457

Silva, F. C., Abreu, M. F., Pérez, D. V., Eira, P. A., Abreu, C. A., Van Raij, B., ... Barreto, W. O. (2009). Métodos de análises químicas para avaliação da fertilidade do solo. In F. C. Silva (Ed.), Manual de análises químicas de solos, plantas e fertilizantes (2nd ed., pp. 107-189). Brasília: Embrapa.

Silva, R. G., Galvao, J. C. C., Miranda, G. V., Silva, D. G., \& Arnhold, E. (2007). Produtividade de milho em diferentes sistemas produtivos. Revista Verde, 2(2), 136-141.

Sisinno, C. L. S., Pereira Netto, A. D., Rego, E. C. P., \& Lima, G. S. V. (2003). Hidrocarbonetos policíclicos aromáticos em resíduos sólidos industriais: Uma avaliação preliminar do risco potencial de contaminação ambiental e humana em áreas de disposição de resíduos. Cadernos de Saúde Pública, 19(2), 671-676. https://doi.org/10.1590/S0102-311X2003000200035

Streck, N. A., Lago, I., Samboranha, F. K., Gabriel, L. F. schwantes, A. P., \& Schons, A. (2009). Temperatura base para aparecimento de folhas e filocrono da variedade de milho BRS Missões. Ciência Rural, 39(1), 224-227. https://doi.org/10.1590/S0103-84782009000100035

Taiz, L., \& Zeiger, E. (2013). Fisiologia vegetal (pp. 1-954). Editora: Artmed.

Vital, A. F. M., Santos, D., \& Santos, R. V. (2015). Características agronômicas do milheto adubado com diferentes fontes orgânicas. Agropecuária Técnica, 36(1), 303-309. https://doi.org/10.25066/agrotec. v36il. 24598

\section{Copyrights}

Copyright for this article is retained by the author(s), with first publication rights granted to the journal.

This is an open-access article distributed under the terms and conditions of the Creative Commons Attribution license (http://creativecommons.org/licenses/by/4.0/). 